\title{
INFLUENCE OF FROND, STEM AND ROOTS OF OIL PALM SEEDLINGS IN VERMICOMPOST FROM OIL PALM BIOMASS
}

\author{
Z NAHRUL HAYAWIN*; ASTIMAR, A A*; R NUR RASHYEDA*; J NOR FAIZAH*; J IDRIS**; N RAVI \\ MENON $^{\star} ; Z$ BIDATTUL SYIRAT $;$ M ROPANDI* and ANAFIAH HAMZAH ${ }^{\ddagger}$
}

\begin{abstract}
Chemical fertilisers contribute significantly to palm oil's cost of production. There are also concerns that the uncontrolled use of chemical fertilisers can have negative implications on the environment. Many studies have evaluated alternatives not only to reduce costs but also to avoid complications associated with environmental pollution. This study investigated the viability of vermicompost cultivated in a media comprising oil palm empty fruit bunch (OPEFB) and anaerobically digested palm oil mill effluent (POME). Both these substances are abundantly available in Malaysia as by-products of the palm oil industry. Vermicompost application trials were conducted to study the growth pattern of the fronds and the stem heights of oil palm seedlings during the one-year trial period. Three distinct regimes were selected for these trials based on three different compositions of vermicompost: 100\% OPEFB and POME (coded as V1), a mixture comprised of V1 and a chemical fertiliser at a ratio of 70\%:30\%, and 100\% chemical fertiliser. The three fertiliser regimes were applied to three batches of three-month old oil palm seedlings at an oil palm nursery. The first regime, which involved treatment with $100 \%$ V1, showed a significant increase in the number of fronds (8.0), as well as in their heights $(98.1 \mathrm{~cm})$, at the end of the trial period. The results were comparable with those obtained for the other two regimes. The fronds, stems and roots (dry weight) of the $V 1$ seedlings weighed $647 \mathrm{~g}, 274 \mathrm{~g}$ and $150 \mathrm{~g}$ per plant, respectively. These figures were higher than the corresponding values for the seedlings treated with $100 \%$ chemical fertiliser. The cation exchange capacity of the soil in which the V1 seedlings grew was also found to be higher than that of the soil treated with the other two regimes. Therefore, this study suggests that V1 exhibits good potential to be a viable substitute for chemical fertilisers.
\end{abstract}

Keywords: oil palm biomass, oil palm seedling, earthworm, vermicompost.

Date received: 25 July 2016; Sent for revision: 26 July 2016; Received in final form: 28 September 2016; Accepted: 7 October 2016.

\footnotetext{
* Malaysian Palm Oil Board, 6 Persiaran Institusi, Bandar Baru Bangi, 43000 Kajang, Selangor, Malaysia. E-mail: nahrul.hayawin@mpob.gov.my

** Faculty of Chemical Engineering, Universiti Teknologi MARA (UiTM) Sarawak, 94300, Kota Samarahan, Sarawak, Malaysia.

\# Division of Environmental Technology, School of Industrial, Technology, Universiti Sains Malaysia, 11800 Minden, Pulau Pinang, Malaysia.

\# Department of Civil Engineering, Politeknik Merlimau, 77300 Merlimau, Melaka, Malaysia.
}

\section{INTRODUCTION}

The oil palm is the most widely available perennial crop in Malaysia and it has dominated the country's landscape for nearly a century now. It is a major contributor to the Malaysian economy. In 2015, the total value of oil palm product exports amounted to RM 60.17 billion (MPOB, 2015). On average, oil palm plantations and the associated processing industry are capable of generating 80 million tonnes 
of waste by-products, including oil palm empty fruit bunch (OPEFB) and palm oil mill effluent (POME), per year (MPOB, 2014). The raw OPEFB contains approximately $70 \%$ moisture. Hence, the cost to transport OPEFB would be prohibitive if a factory intends using OPEFB to fuel its biomass boilers. Furthermore, OPEFB is not that attractive as fuel because of its poor calorific value (CV) of $5500 \mathrm{~kJ}$ $\mathrm{kg}^{-1}$ in its raw form (in comparison, coal has a CV of about $\left.40000 \mathrm{~kJ} \mathrm{~kg}^{-1}\right)$. However, it can be used for mulching in the oil palm plantations because it can serve as a soil conditioner for erosion control and soil moisture conservation (Krishnan et al., 2016). Owing to their relative abundance, both OPEFB and POME have received a great deal of attention with regard to producing value-added products such as a form of biofertiliser.

As almost all the research trials designed to identify a viable use for the two biomass by-products were successful, the production of compost seems to offer the best solution, since the compost can absorb not only OPEFB but also POME. The only negative element involved in the production of compost was the excessive biodegradation period necessary for the two raw materials to evolve into the mature compost. However, the introduction of a vermicomposting technique using specially selected earthworms was found to effectively overcome this problem by shortening the composting time. Several studies on the composting of OPEFB with POME into value-added products have previously been reported (Chaikitkaew et al., 2015; Krishnan et al., 2016; Yahya et al., 2013). In terms of the environmental and economic concerns, the composting of OPEFB and POME using earthworms (i.e. vermicomposting) was found to produce good quality fertiliser that could also function as a soil conditioner for sustainable soil fertility management [nitrogen $(\mathrm{N}) 1.11 \%$, phosphorus $(\mathrm{P}) 0.44 \%$ and potassium (K) $0.60 \%$ ) (Nahrul Hayawin et al., 2010)].

Vermicomposting is a decomposition process involving interactions between earthworms and microorganisms. Importantly, it is an economical, viable and sustainable option for oil palm waste management. We have previously reported that the vermicomposting of OPEFB and POME using earthworms (Eudrilus eugeniae and Eisenia fetida) has produced acceptable levels of N, P and K that could be used as a biofertiliser (Nahrul Hayawin et al., 2010; 2011; 2012). However, the effect of vermicomposting using OPEFB and POME on the growth of oil palm seedlings has not yet been studied in depth. Therefore, in this study, trials were conducted to investigate the optimum ratio of raw materials that would yield the best vermicompost based on its effect on seedling growth (i.e. the stem height and frond production). The trials involved the use of a combination of OPEFB and POME in one regime (coded as V1), while the second regime involved V1 mixed with a chemical fertiliser at a ratio of 70\%:30\%, and the third regime featured 100\% chemical fertiliser. In this study, an attempt was made to determine the effect of the three fertiliser regimes on the growth patterns of oil palm seedlings. Further, the relative merits of a 100\% chemical fertiliser and vermicompost in combination with a chemical fertiliser were compared.

\section{MATERIALS AND METHODS}

\section{Preparation of Raw Materials}

The materials used in this study for the composting trials were OPEFB and POME sludge. The shredded and pressed OPEFB was collected from the Sri Langat Palm Oil Mill in Dengkil, Sepang, Malaysia. The POME solid was obtained from the Malaysian Palm Oil Board Palm Oil Mill Technology Centre's wastewater treatment plant, which is located at Labu, Negeri Sembilan, Malaysia. The earthworm species used in the trials was Eudrilus eugeniae, commonly known as the African Nightcrawler, and the worms were obtained from a local worm breeder in Malaysia. The breeding stock was maintained at a temperature of $25 \pm 1^{\circ} \mathrm{C}$ and only mature clitellate earthworms were used in this investigation. The composting processes and the subsequent vermicomposting were carried out by Nahrul Hayawin et al. (2013). The following parameters were determined for the sampling analysis method: the total organic carbon was estimated using the standard dichromate oxidation method of Nelson and Sommers (1982); a CX-732 digital multimeter (Elmetron, Zabrze, PL) was used for the $\mathrm{pH}$ measurements with a ROSS Sure-Flow ${ }^{\mathrm{TM}}$ Orion pH electrode (Beverly, USA); the total Kjeldahl nitrogen (TKN) and the total phosphorus (TP) were determined according to the spectrophotometric method using a SQ 118 Merck (Darmstadt, Germany); the $\mathrm{C} / \mathrm{N}$ ratio was calculated from the measured $\mathrm{C}$ and $\mathrm{N}$ values; the ammonium acetate method for exchangeable cations, the chromium and lead concentrations were determined by flame atomic absorption spectroscopy (FAAS) using a PerkinElmer AAnalyst 800 (Shelton, USA); and the potassium concentration was determined by atomic emission spectroscopy using a Philips PU9100X (Cambridge, UK).

\section{Study Site and Plant Materials}

The trials were conducted at the MPOB Kluang Research Station, Johor, Malaysia $\left(02^{\circ} 02^{\prime} 24^{\prime \prime} \mathrm{N}\right.$, $\left.103^{\circ} 19^{\prime} 12^{\prime \prime} \mathrm{E}\right)$. Polybags were filled with $18 \mathrm{~kg}$ of topsoil and left for three to four weeks before the seedlings were planted. The polybags were filled with the soil, leaving an empty space $50 \mathrm{~mm}$ from 
the top to allow room for the fertiliser and water that needed to be applied from time to time. The oil palm seedlings were planted in the polybags using an auger to facilitate accelerated planting. The trials commenced when the seedlings were three-month old. Three different treatment regimes were applied to the oil palm seedlings: the first regime involved V1 (a mixture of OPEFB and POME), the second regime involved V1 and a chemical fertiliser at a ratio of 70\%:30\%, and the third regime involved a chemical fertiliser $(100 \%)$ as a control. Details regarding the composition of the different treatment regimes are shown in Table 1. It is important to note that the fertiliser application interval arbitrarily chosen for the first two regimes was $3 \mathrm{~kg}$ per plant at twomonth intervals, while for the chemical fertiliser the application interval was chosen according to the instructions on the packaging following the MPOB Code of Good Nursery Practice for Oil Palm Nurseries (CoPN). Each treatment of five replications consisted of 50 oil palm seedlings in a polybag $15 \mathrm{~cm}$ $\times 23 \mathrm{~cm}$ in size with the thickness of $0.10 \mathrm{~mm}$. The seedlings were planted using a triangular spacing of $0.9 \mathrm{~m} \times 0.9 \mathrm{~m} \times 0.9 \mathrm{~m}$ and arranged in an eastwest direction in a small nursery plot. Water was applied through an overhead sprinkler system and all the necessary good nursery practices and plant protection measures were followed uniformly for all the treatments during the entire trial period. Water sprayings were carried out twice a day, early in the morning and late in the evening, delivering $500 \mathrm{ml}-$
1.5 litres of water per seedling per year of planting. The data were collected at two-month intervals and careful observations were made of the soil treatments, height of the plants, number of fronds and the shoot:root ratio when the seedlings were nine-month old. Soil concentrations were collected at 12-month old oil palms during harvesting using stainless steel soil auger [extensions pre-labelled in $15.24 \mathrm{~cm}\left(6^{\prime \prime}\right)$ increments] and sent to laboratory for soil concentration analysis.

\section{Statistical Analysis}

The data in this study were analysed statistically by means of a one-way analysis of variance (ANOVA) in a general linear model using Statistical Analysis System (SAS) software. All the values are presented as the mean \pm SD. The probability levels used for statistical significance were $p \leq 0.05$.

\section{RESULTS AND DISCUSSION}

\section{Characteristics of the Vermicomposts}

Table 2 shows the physico-chemical characteristics of the vermicomposts obtained from the different ratios of OPEFB with the addition of POME reported in our previous study (Nahrul Hayawin et al., 2012). The $\mathrm{pH}$ values obtained during the vermicomposting process ranged between 7.9 and

TABLE 1. FERTILISED OIL PALM SEEDLINGS AT THE NURSERY STAGE

\begin{tabular}{|c|c|c|c|c|}
\hline \multirow[b]{2}{*}{$\begin{array}{l}\text { Age of oil } \\
\text { palm seedling } \\
\text { (months) }\end{array}$} & \multirow[b]{2}{*}{ Frequency } & \multicolumn{3}{|c|}{ Treatment } \\
\hline & & $\begin{array}{c}\mathrm{V} 1 \\
(100 \%)(\mathrm{kg})\end{array}$ & $\begin{array}{c}\text { V1 } \\
+ \text { Chemical fertiliser (kg) } \\
(70 \%+30 \%)\end{array}$ & $\begin{array}{l}\text { Chem. fertiliser (g) } \\
\text { (12:12:12:17:2 + TE) }\end{array}$ \\
\hline 3 & 2 & 3 & 3 & 15 \\
\hline 4 & 2 & - & - & - \\
\hline 5 & 2 & 3 & 3 & 28 \\
\hline 6 & 2 & - & - & - \\
\hline 7 & 2 & 3 & 3 & 42 \\
\hline 8 & 2 & - & - & - \\
\hline 9 & 2 & 3 & 3 & 56 \\
\hline 10 & 3 & - & - & - \\
\hline 11 & 1 & 3 & 3 & 70 \\
\hline 12 & 1 & - & - & - \\
\hline
\end{tabular}

TABLE 2. PHYSICO-CHEMICAL CHARACTERISTICS OF THE VERMICOMPOSTS OBTAINED FROM DIFFERENT RATIOS OF OIL PALM EMPTY FRUIT BUNCHES (OPEFB) WITH THE ADDITION OF PALM OIL MILL EFFLUENT (POME) ANAEROBIC SLUDGE

\begin{tabular}{|c|c|c|c|c|}
\hline OPEFB $(100 \%)$ & $7.9 \pm 0.2$ & $0.4 \pm 0.1$ & $0.2 \pm 0.1$ & $0.06 \pm 0.0$ \\
\hline
\end{tabular}


8.5, which are considered suitable in terms of soil fertility for oil palm seedlings. The $\mathrm{N}, \mathrm{P}$ and $\mathrm{K}$ contents were $1.7 \%, 1.4 \mathrm{mg} \mathrm{kg}^{-1}$ and $0.5 \mathrm{mg} \mathrm{kg}^{-1}$, respectively, in the final vermicompost consisting of an equal proportion of OPEFB and POME, which is comparable with the vermicompost consisting of solely OPEFB (100\%). The mixing of up to $50 \%$ POME with OPEFB could accelerate the mineralisation of the nutrients in the soil and hence increase the oil palm seedlings' growth.

\section{Growth of Oil Palm Seedlings}

The addition of vermicompost in the soil has been shown to result in a marked increase in the heights of the oil palm seedlings' stems after six months when the seedlings were transferred to the large polybags, particularly those seedlings blended with a chemical fertiliser, as shown in Table 3. The plant heights and the number of fronds of the oil palm seedlings treated with vermicompost both showed a significant increase. Based on the percentage increase observed in the number of fronds on the seedlings treated with various rates and types of fertiliser, the positive role of V1 in combination with a chemical fertiliser at a 70:30 ratio could be established. The percentage of stem growth was calculated by deducting the height of the oil palm stem at the end of each experiment from the height at the onset of the trial. The highest percentage increase in stem height was found to be $65.27 \%$ for the $70: 30$ ratio mix of $\mathrm{V} 1$ and a chemical fertiliser, followed by a $38.53 \%$ increase for the vermicompost (V1) and a $26.18 \%$ increase for the chemical fertiliser. The highest registered percentage increase in the seedlings' stem height was $60.22 \%$, again for the $70: 30$ ratio mix of V1 and a chemical fertiliser, which was followed by a $48.34 \%$ increase for V1 and a $25.29 \%$ increase for the chemical fertiliser.

The oil palm seedlings grown in vermicompost mixtures containing 30\% chemical fertiliser gave rise to significantly larger $(\mathrm{p} \leq 0.05)$ frond dry weights, stem dry weights and shoot:root ratios than those grown in solely V1 or chemical fertilisers (Table 4). The oil palm seedlings treated with V1 produced greater frond dry weights, stem dry weights and root dry weights of $647.50 \mathrm{~g}, 274.50 \mathrm{~g}$ and $150.70 \mathrm{~g}$ per plant, respectively, than those treated with just a chemical fertiliser. Vermicomposting is reported to produce hormone-like activity, which has been hypothesised to result in greater root initiation, increased root biomass, enhanced plant growth and development, and altered morphology of plants grown in vermicompost-amended media (Bharti et al., 2016; Yang et al., 2015).

TABLE 3. VEGETATIVE GROWTH OF OIL PALM SEEDLINGS UNDER DIFFERENT TREATMENTS

\begin{tabular}{|c|c|c|c|c|c|c|}
\hline Seedling age & $\begin{array}{c}\mathrm{V} 1 \\
(100 \%)\end{array}$ & $\begin{array}{c}\mathrm{V} 1(70 \%)+ \\
\text { chemical }(30 \%)\end{array}$ & $\begin{array}{c}\text { Control } \\
\text { (chemical } \\
\text { 12:12:17:2) }\end{array}$ & V1 $(100 \%)$ & $\begin{array}{c}\mathrm{V} 1(70 \%)+ \\
\text { chemical }(30 \%)\end{array}$ & $\begin{array}{l}\text { Chemical } \\
\text { 12:12:17:2) }\end{array}$ \\
\hline 3 & $7.7 \pm 1.7 \mathrm{ab}$ & $8.4 \pm 1.8 \mathrm{a}$ & $7.1 \pm 1.8 b$ & $82.9 \pm 11.9 a$ & $83.6 \pm 12.5 a$ & $74.7 \pm 12.6 b$ \\
\hline 4 & $8.0 \pm 2.3 b$ & $9.4 \pm 2.4 a$ & $8.0 \pm 2.2 b$ & $98.1 \pm 17.7 \mathrm{a}$ & $102.3 \pm 12.8 a$ & $87.0 \pm 13.6 b$ \\
\hline
\end{tabular}

Note: *Mean of 50 seedlings per treatment. Mean value followed by different letters is statistically different (ANOVA; Tukey's test, $\mathrm{p} \leq 0.05$ ).

TABLE 4. DRY WEIGHT OF STEMS, ROOTS AND FRONDS OF OIL PALM SEEDLINGS SUBJECTED TO DIFFERENT FERTILISER TREATMENTS*

\begin{tabular}{lcccc}
\hline Treatment & Frond (dry wt.) & Stem (dry wt.) & Root (dry wt.) & Shoot:root \\
\cline { 2 - 3 } & & g per plant & \\
\hline V1 $(100 \%)$ & $647.5 \pm 20.4 \mathrm{a}$ & $274.5 \pm 37.9 \mathrm{a}$ & $150.7 \pm 10.9 \mathrm{~b}$ & 5.3 \\
$\begin{array}{l}\text { V1 }(70 \%)+\text { chemical } \\
\text { fertiliser }(30 \%)\end{array}$ & $878.8 \pm 36.1 \mathrm{ab}$ & $329.3 \pm 25.8 \mathrm{ab}$ & $168.8 \pm 42.5 \mathrm{a}$ & \\
$\begin{array}{l}\text { Chemical fertiliser } \\
(12: 12: 17: 2)\end{array}$ & $334.2 \pm 29.0 \mathrm{~b}$ & $155.2 \pm 14.7 \mathrm{~b}$ & $135.1 \pm 14.2 \mathrm{ab}$ & 2.5 \\
\hline
\end{tabular}

Note: *Mean of 50 seedlings per treatment. Mean value followed by different letters is statistically different (ANOVA; Tukey's test, $\mathrm{p} \leq$ 0.05). 


\section{Soil Nutrient Concentration}

The soil nutrient contents of 12-month old oil palms treated with the V1, V1 plus chemical (70\%:30\%) and chemical fertiliser applications are shown in Table 5. The cation exchange capacity (CEC) of the soil treatments was lower in the chemical fertiliser treatment relative to the vermicompost. The CEC of the soil treatments was highest in the V1 treatment when compared to the other treatments. The $\mathrm{N}$ and $\mathrm{P}$ in the soil that had been treated with the $30 \%$ chemical vermicompost fertiliser were $0.18 \%$ and $262.32 \mathrm{mg} \mathrm{kg}^{-1}$, respectively, whereas the $\mathrm{N}$ and $\mathrm{P}$ were only $0.11 \%$ and 142.11 $\mathrm{mg} \mathrm{kg}^{-1}$, respectively, in the soils that had been treated with the chemical fertiliser (Table 5). Thus, the $\mathrm{N}$ and $\mathrm{P}$ in the soils that received V1 $(70 \%)$ plus a chemical fertiliser (30\%) were $65.45 \%$ and $84.59 \%$ higher, respectively, than the $\mathrm{N}$ and $\mathrm{P}$ in the soils that received the control (chemical) fertiliser. It is suggested that, in addition to releasing $\mathrm{N}$ from the compost material, earthworm activity also enhances the nitrogen levels in the soil by adding excretory equilibrium among the forms of $\mathrm{K}$ from relatively unavailable to more available forms in the soil (ElHadad et al., 2014). The $\mathrm{C} / \mathrm{N}$ ratio of the control (chemical) fertiliser in the soil was 9.45, whereas it was 10.95 for the $30 \%$ chemical vermicompost fertiliser and $11 \%$ for the V1 (Table 5). A C/N ratio $<20$ indicates acceptable maturity in the finished product (El-Haddad et al., 2014; Pandit et al., 2012), although a ratio $\leq 10$ is preferred for the optimal growth of oil palms.

\section{CONCLUSION}

The palm oil industry is under pressure to demonstrate conformance to sustainability. The use of chemical fertilisers is one factor which can negate palm oil's sustainability score. This arises from its potential pollution impact on the environment. This study was conducted to assess the performance of one possible alternative, vermicompost made from a mixture of OPEFB and POME (coded as V1) using the earthworm Eudrilus Eugeniae to accelerate

TABLE 5. SOIL NUTRIENT CONTENT OF 12-MONTH OLD OIL PALMS SUBJECTED TO DIFFERENT FERTILISER TREATMENTS*

\begin{tabular}{lccccc}
\hline Treatment & $\begin{array}{c}\text { CEC } \\
\mathbf{c m o l}(+)\left(\mathbf{k g}^{-1}\right)\end{array}$ & $\begin{array}{c}\mathbf{N} \\
\mathbf{( \% )}\end{array}$ & $\begin{array}{c}\mathbf{P} \\
\left(\mathbf{m g ~ k g}^{-1}\right)\end{array}$ & $\begin{array}{c}\mathbf{K} \\
\left(\mathbf{m g ~ k g}^{-1}\right)\end{array}$ & $\mathbf{C} / \mathbf{N}$ \\
\hline V1 (100\%) & $6.59 \pm 0.87 \mathrm{~b}$ & $0.16 \pm 0.05 \mathrm{a}$ & $231.28 \pm 94.37 \mathrm{ab}$ & $1.53 \pm 0.22 \mathrm{a}$ & 11.00 \\
$\begin{array}{c}\text { V1 }(70 \%)+\text { chemical } \\
\text { fertiliser (30\%) }\end{array}$ & $6.32 \pm 0.31 \mathrm{~b}$ & $0.18 \pm 0.05 \mathrm{a}$ & $262.32 \pm 98.15 \mathrm{a}$ & $1.79 \pm 0.18 \mathrm{a}$ & 10.95 \\
$\begin{array}{c}\text { Chemical fertiliser } \\
(12: 12: 17: 2)\end{array}$ & $4.43 \pm 0.87 \mathrm{c}$ & $0.11 \pm 0.05 \mathrm{~b}$ & $142.11 \pm 15.69 \mathrm{~b}$ & $0.98 \pm 0.22 \mathrm{~b}$ & 9.45 \\
\hline
\end{tabular}

Note: *Values followed by the same letter in the same column are not significantly different from one another at the $5 \%$ probability level (ANOVA; Tukey's test, $\mathrm{p} \leq 0.05$ ). CEC - cation exchange capacity.

products, mucus, body fluids and enzymes etc. to the substrate. Ravindran et al. (2015) suggested that the decaying tissues of dead worms also add a significant amount of $\mathrm{N}$ to the vermicomposting subsystem. Earthworms stimulate P uptake from the re-distribution of organic matter and by increasing the enzymatic activation of phosphatase (Zhang et al., 2011). The increase in $P$ availability due to the increase in the solubility of $\mathrm{P}$ as a result of higher phosphatase activity following the application of vermicompost was reported by Yang et al. (2015).

The $\mathrm{K}$ in the soils that had received $30 \%$ chemical vermicompost fertiliser was $1.788 \mathrm{mg} \mathrm{kg}^{-1}$, whereas the $\mathrm{K}$ was only $0.98 \mathrm{mg} \mathrm{kg}^{-1}$ in the soils that had received the control (chemical) fertiliser (Table 5 ). The slight increase in the $\mathrm{K}$ may be the result of the increase in $\mathrm{K}$ availability due to the shifting the decomposition process. From the results of the trials conducted to evaluate the growth patterns of the oil palm seedlings, it was found that after nine months of planting, the treatment comprising V1 and a chemical fertiliser at a ratio of 70\%:30\% gave the best results in terms of stem growth and frond production, followed by the V1 on its own and then the chemical fertiliser. The oil palm seedlings treated with V1 produced greater frond dry weights, stem dry weights and root dry weights of $647 \mathrm{~g}, 274 \mathrm{~g}$ and $150 \mathrm{~g}$ per plant, respectively, which were higher than those produced when using solely chemical fertiliser but comparable with those produced when using a mixture of V1 and a chemical fertiliser. The CEC in the V1 plus chemical fertiliser treated soil was also found to be higher than that in the other treatment regimes. 
Vermicompost can be used as a good substitute for chemical fertilisers, thus promoting the sustainability of the oil palm industry.

\section{ACKNOWLEDGEMENT}

The first author would like to thank the DirectorGeneral of MPOB for the financial support provided for conducting this study. The authors are grateful to all staff of MPOB, as well as to the reviewers for their valuable comments and careful revision of this manuscript.

\section{REFERENCES}

BHARTI, N; BARNAWAL, D; SHUKLA, S; TEWARI, S K; KATIYAR, T S and KALRA, A (2016). Integrated application of Exiguobacterium oxidotolerans, Glomus fasciculatum, and vermicompost improves growth, yield and quality of Mentha arvensis in salt-stressed soils. Industrial Crops and Products, 83: $717-728$

CHAIKITKAEW, S; KONGJAN, $\mathrm{P}$ and O-THONG, S (2015). Biogas production from biomass residues of palm oil mill by solid state anaerobic digestion. 2015 International Conference on Alternative Energy in Developing Countries and Emerging Economies. Energy Procedia, 79: 838-844.

EL-HADDAD, M E; ZAYED, M S; EL-SAYED, G A M; HASSANEIN, M K and ABD EL-SATAR, A M (2014). Evaluation of compost, vermicompost and their teas produced from rice straw as affected by addition of different supplements. Annals of Agricultural Science, 59(2): 243-251.

KRISHNAN, Y; BONG, C P C; AZMAN, N F; ZAKARIA, Z; OTHMAN, N A; ABDULLAH, N; HO, C S; LEE, C T; HANSEN, S B and HARA, H (2016). Co-composting of palm empty fruit bunch and palm oil mill effluent: microbial diversity and potential mitigation of greenhouse gas emission. J. Cleaner Production. http://dx.doi.org/10.1016/j. jclepro.2016.08.118

MPOB (2015). Malaysian Oil Palm Statistics. http:/ / bepi.mpob.gov.my/index.php/statistics / export/138-export-2015/759-monthly-export-ofoil-palm products-2015.html

MPOB (2014). Malaysian Oil Palm Statistics. http:/ / bepi.mpob.gov.my/index.php/statistics / export/ 138-export-2015/759-monthly-export-ofoil-palm products-2014.html

NAHRUL HAYAWIN, Z; ABDUL KHALIL, H $P$ S; JAWAID, $\mathrm{M}$; HAKIMI IBRAHIM, $\mathrm{M}$ and
ASTIMAR, A A (2010). Exploring chemical analysis of vermicompost of various oil palm fibre wastes. Environmentalist, 30: 273-278.

NAHRUL HAYAWIN, Z; ASTIMAR, A A; HAKIMI IBRAHIM, M; WAN HASAMUDIN, $\mathrm{W} \mathrm{H}$ and ABDUL KHALIL, H P S (2011). Vermicomposting of different types of oil palm fibre waste using Eudrilus eugeniae: a comparative study. J. Oil Palm Res. Vol. 23: 979-989.

NAHRUL HAYAWIN, Z; ASTIMAR, A A; ANIS, M; HAKIMI IBRAHIM, M; ABDUL KHALIL, H P S and ZAWAWI, I (2012). Vermicomposting of empty fruit bunch with addition of solid palm oil mill effluent. J. Oil Palm Res. Vol. 24: 1542-1549.

NAHRULHAYAWIN,Z; ASTIMAR,AA;RIDZUAN, R; BIDATTUL SYIRAT, Z; RAVI MENON, N and NOR FAIZAH, J (2013). Study on the effect of zeolite and other bio-adsorbants in enhancing the quality of the palm based vermicompost. Online International Interdisciplinary Research J., 3: 51-61.

NELSON, D W and SOMMERS, L E (1982). Total carbon and organic carbon. Methods of Soil Analysis (Page, A L; Miller, R H and Keeney, D R eds.). Amer. Soc. Agron. Inc., Madison, W.I. p. 539-579.

PANDIT, N P; AHMAD, N and MAHESHWARI, S K (2012). Vermicomposting biotechnology an eco-loving approach for recycling of solid organic wastes into valuable biofertilizers. J. Biofertilizers and Biopesticides, 3: 1-8.

RAVINDRAN, B; CONTRERAS-RAMOS, S M and SEKARAN, G (2015). Changes in earthworm gut associated enzymes and microbial diversity on the treatment of fermented tannery waste using epigeic earthworm Eudrilus eugeniae. Ecological Engineering, 74: 394- 401.

YAHYA, A; SYE, C P; ISHOLA, T A and SURYANTO, $H$ (2013). Effect of adding palm oil mill decanter cake slurry with regular turning operation on the composting process and quality of compost from oil palm empty fruit bunches. Bioresource Technology, 101: 8736-8741.

YANG, L; ZHAO, F; CHANG, Q; LI, T and LI, F (2015). Effects of vermicomposts on tomato yield and quality and soil fertility in greenhouse under different soil water regimes. Agricultural Water Management, 160: 98-105.

ZHANG, N; REN, Y; SHI, Q; WANG, X; WEI, M and YANG, $F$ (2011). Effects of vermicompost on quality and yield of watermelon. China Veg., 6: 76 -79 (in Chinese with English abstract). 